\title{
ENGLISH TRAINING USING MACROMEDIA FLASH IN ENGLISH LEARNING FOR PAUD TEACHERS IN SENGKANG
}

\author{
Ahmad Munawir ${ }^{*}$ \\ Syahrun Adzim² \\ 1,2 Institut Agama Islam As'adiyah Sengkang, Sengkang, Indonesia \\ ahmadmunawirbugis@gmail.com ${ }^{1^{*}}$ \\ syahrunadzim@gmail.com ${ }^{2}$
}

Keywords: [English Training, Macromedia Flash, PAUD Teachers]

\begin{abstract}
Learning English and introducing technology to children at a young age is becoming increasingly important in order to meet the demands of an era in which everything is now done in English and is based on technology. To do this, people resources are required who are fluent in two languages: English and technology, both of which are currently unavailable. This is due to a lack of understanding and mastery of technologybased English, which is one of them. The Community Service team of IAI As'adiyah held activities with practical methods related learning English based on macromedia flash based on the previous Community Service program carried out by FTK IAI As'adiyah Sengkang academics, which included training on the use of word and excel. It is envisaged that as a result of this project, PAUD teachers in the Sengkang City area will have more abilities and knowledge in technology-based English education, particularly employing macromedia flash.
\end{abstract}

Published by:

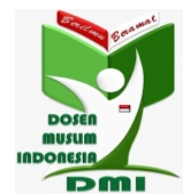

Copyright (C) 2021 The Author(s)

This article is licensed under CC BY 4.0 License (cc) $\mathrm{BY}$

\section{Introduction}

https://dmi-journals.org/jai 
Today, the development of technology is growing rapidly. The use of technology has been increasingly calculated to facilitate human work. The utilization of technology covers various fields, including medicine, economics, society, and education (Klaassen, 2018; Budd et al., 2020; Simamarta et al., 2020; Simamarta et al., 2021). However, there are still many people who have not used technology in their daily lives due to a lack of understanding and knowledge of technology (Schultze \& Boland Jr, 2000; Ranchhod \& Zhou, 2001; Sulistyawati et al., 2018; Hendayani, 2019; Waizenegger et al., 2020). The introduction of technology to early childhood is very important to provide knowledge of the benefits of technology itself, especially since everything is always related to technology. In fact, technology can help the teaching and learning process convey information more effectively (Ezziane, 2007; Negrete \& Lartigue, 2004; Shagiyeva, 2020; Hernandez-de-Menendez et al., 2020). This, of course, can help make it easier for children to receive information easily. The introduction of technology to early childhood is, of course, done as attractively as possible so that it can provide a special attraction for them to be able to easily receive all the information.

Language is a human ability that is used to communicate. Without language, communication will not work well (Mercer, 2002; Andersen \& Rasmussen, 2004; Marsh \& Langé, 2000). Language is needed to communicate with other people, both verbal and nonverbal. Today, to be able to communicate with people with a very broad scope, one can use an international language, namely English. English is an international language that can be used to communicate with other people from all over the world (Smith, 2005; Clyne \& Sharifian, 2008; Le Ha, 2009; Agustin, 2015). To be able to communicate, understanding and mastery of English are also needed. An introduction to basic English is also needed from an early age to provide an understanding of English at a higher level. English will be easier to teach to children from a young age because they can easily imitate and practice their language skills at this age (Wulanjani, 2016; Arumsari et al., 2017; Pinter, 2017).

Because the language used daily is Indonesian, it is still difficult for early childhood to accept English. Of course, they still feel foreign to English, so it is still difficult to accept foreign languages.

Interactive learning media will make it easier for students to remember the material presented by the teacher because it will be presented in a pleasant display. Where the learning media can increase students' creativity and effectiveness in learning (Murtafiah et al., 2019; Kariadi et al., 2021).

The absence of interest in early childhood in accepting foreign languages makes PAUD teachers in Sengkang City find it difficult to impart knowledge of English. Interactive and interesting English learning media are very much needed for PAUD teachers in Sengkang City to help the teaching and learning process. The utilization of technology can help find solutions to existing problems. The limited understanding and knowledge of technology is an obstacle to being able to solve the problems experienced by PAUD teachers in Sengkang City.

The solution offered is the creation of interactive and attractive English learning media using Macromedia Flash, which is then carried out by socializing the use of Macromedia Flash, which can help the teaching and learning process. With existing technological advances, learning media are not just books and manual teaching aids, but also turn to digital multimedia. IAI As'Adiyah Sengkang Community Service that has been 
carried out at PAUD teachers in Sengkang City previously was training to use Microsoft Office. Children's understanding of Microsoft Office alone is not effective because PAUD teachers in Sengkang City need to have more interesting interactive media in the form of audio-visuals to attract children's attention so they can understand English more easily.

Macromedia Flash is an application program that combines application programs that combine visual and audio (Saputra \& Tiarina, 2013; Pratiwi, 2016; Irawan et al., 2019; Hanief \& Supuwiningsih, 2020). Macromedia flash-based media is easy to operate because the menus that are displayed are not too many and easy (Rapo \& Michael, 2013; Deiniatur, 2019)

With these problems and solutions, the IAI As'adiyah Sengkang Community Service team this time will socialize the use of Macromedia Flash-based English learning media in the hope of helping the teaching and learning process of PAUD teachers in Sengkang City provide interactive and interesting English learning. so that it can increase interest in learning English at an early age.

\section{Implementation Method}

The method used in "Macromedia Flash-based English Teaching" will be given in the form of a hands-on practicum. The place for community service is in Hall 1 of IAI As'adiyah Sengkang, which lasts for 3 hours, and the time for this community service is January 11, 2019.

Participants in community service regarding Macromedia Flash-based English learning are PAUD teachers in the Sengkang City area. With the increase in the ability to teach English based on Macromedia Flash, it is hoped that PAUD teachers in the Sengkang City area can enrich their knowledge and abilities in the field of technology-based English teaching.

The selection of PAUD teacher service partners in the Sengkang City area is because this area is closest to the location of IAI As'adiyah Sengkang. Because it is hoped that the dissemination of knowledge about technology will start from the nearest area first, it is very suitable to hold Macromedia flash-based English learning training in this place.

\section{Results and Discussion}

\section{Analysis Results}

The analysis of these results was obtained based on the evaluation of the results of the questionnaire that had been given to 30 participants of Community Service (PKM) regarding Macromedia Flash-based English teaching to PAUD teachers in the Sengkang City area as follows in Table 1.

Table 1. Results of Questionnaire Analysis

\begin{tabular}{lcc}
\hline \multicolumn{1}{c}{ Questions } & $\begin{array}{c}\text { Percentage } \\
\text { (\%) }\end{array}$ & Description \\
\hline $\begin{array}{l}\text { Are you familiar with Macromedia Flash for } \\
\text { learning tools? }\end{array}$ & 93 & Don't Know \\
& 7 & Done, but not optimal \\
\hline
\end{tabular}




\begin{tabular}{lcc}
\hline \multicolumn{1}{c}{ Questions } & $\begin{array}{c}\text { Percentage } \\
(\mathbf{\%})\end{array}$ & Description \\
\hline $\begin{array}{l}\text { Does this service provide insight into the use } \\
\text { of Macromedia Flash for teaching and }\end{array}$ & 90 & Open the knowledge \\
learning? & 10 & Never \\
$\begin{array}{l}\text { Do you feel the need to use Macromedia Flash } \\
\text { for learning tools? }\end{array}$ & 93 & It is necessary \\
$\begin{array}{l}\text { Are you interested in learning English using } \\
\text { Macromedia Flash? }\end{array}$ & 100 & Need \\
$\begin{array}{l}\text { Which is more interesting, learning English } \\
\text { through Macromedia flash or books? }\end{array}$ & 93 & Macromedia Flash \\
$\begin{array}{l}\text { Which do you prefer, learning through } \\
\text { Macromedia flash-based or books? }\end{array}$ & 93 & Macromedia flash and \\
books
\end{tabular}

\section{Activity Evaluation}

The evaluation was carried out from the results of the questionnaire analysis. Participants felt the benefits of holding this training to support teaching and learning activities. By means of macromedia Flash, learning is made more interesting, especially learning English, and can be developed for other subjects as well. Participants are interested in getting further insight about Macromedia Flash and other applications that support Macromedia Flash.

The outcomes achieved from this community service activity include several things, but the main thing for the training participants is to increase the abilities and skills of the participants in using Macromedia Flash in the teaching and learning process, because by using Macromedia Flash, the teaching and learning process becomes more interesting (Saputra \& Tiarina, 2013; Nurani \& Robiasih, 2017; Trisna \& Nasution, 2018). 


\section{Conclusions}

PAUD teachers in the Sengkang city area as Community Service (PKM) participants have gained knowledge about Macromedia Flash, which is very useful to support the teaching and learning process, especially English language training. Because by using Macromedia flash, the teaching and learning process becomes more interesting, systematic, and makes teachers more able to explore ideas for teaching materials. With the existence of an English teaching system based on Macromedia Flash, PAUD teachers in Sengkang City find it easier.

We can give suggestions for further service activities, such as holding special and in-depth training on Macromedia Flash for the general public and especially for PAUD teachers, because with Macromedia Flash, teachers are greatly assisted in creating more interesting and efficient learning tools so that the learning process becomes smoother.

\section{Refereces}

Afshari, M., Bakar, K. A., Luan, W. S., Samah, B. A., \& Fooi, F. S. (2009). Factors affecting teachers' use of information and communication technology. Online Submission, 2(1), 77-104.

Agustin, Y. (2015). Kedudukan bahasa Inggris sebagai bahasa pengantar dalam dunia pendidikan. Deiksis, 3(04), 354-364.

Andersen, H., \& Rasmussen, E. S. (2004). The role of language skills in corporate communication. Corporate Communications: An International Journal.

Arumsari, A. D., Arifin, B., \& Rusnalasari, Z. D. (2017). Pembelajaran Bahasa Inggris pada Anak Usia Dini di Kec Sukolilo Surabaya.Jurnal PG-PAUD Trunojoyo: Jurnal Pendidikan Dan Pembelajaran Anak Usia Dini, 4(2), 133-142.

Budd, J., Miller, B. S., Manning, E. M., Lampos, V., Zhuang, M., Edelstein, M., ... \& McKendry, R. A. (2020). Digital technologies in the public-health response to COVID-19. Nature medicine, 26(8), 1183-1192.

Clyne, M., \& Sharifian, F. (2008). English as an international language: Challenges and possibilities. Australian Review of Applied Linguistics, 31(3), 28-1.

Deiniatur, M. (2019). Developing learning media through macromedia flash application for English phonology class. JURNAL SMART, 5(1), 45-59.

Ezziane, Z. (2007). Information technology literacy: Implications on teaching and learning. Journal of Educational Technologyand Society, 10(3), 175.

Hanief, S., \& Supuwiningsih, N. N. (2020). Learning Tenses With Multimedia For Junior High School Students. In 2020 2nd International Conference on Cybernetics and Intelligent System (ICORIS) (pp. 1-6). IEEE.

Hendayani, M. (2019). Problematika Pengembangan Karakter Peserta Didik Di Era 4.0. Jurnal Penelitian Pendidikan Islam,[SL], 7(2), 183-198.

Hernandez-de-Menendez, M., Díaz, C. A. E., \& Morales-Menendez, R. (2020). Educational experiences with Generation Z. International Journal on Interactive Design and Manufacturing (IJIDeM), 14(3), 847-859. 
Irawan, Y., Wahyuni, R., \& Herianto, H. (2019). Media Pembelajaran Bahasa Inggris Dasar Menggunakan Macromedia Flash 8 di Tk Kartika 1.50 Kecamatan Sail Kota Pekanbaru. Informatika, 11(2), 1-7.

Kariadi, M. T., Riyanton, M., \& Anggraheni, D. (2021). Planning and Developing Creativity Through Media-Based Learning in English Language Teaching. English Review: Journal of English Education, 9(2), 427-436.

Klaassen, R. G. (2018). Interdisciplinary education: a case study. European journal of engineering education, 43(6), 842-859.

Le Ha, P. (2009). English as an international language: International student and identity formation. Language and intercultural communication, 9(3), 201-214.

Marsh, D., \& Langé, G. (2000). Using languages to learn and learning to use languages. Finland: University of Jyväskylä.

Mercer, N. (2002). Words and minds: How we use language to think together. Routledge.

Murtafiah, W., Sa'dijah, C., Tjang, D. C., \& Susiswo, S. (2019). Decision making of the winner of the national student creativity program in designing ICT-based learning media. TEM Journal, 8(3), 1039.

Negrete, A., \& Lartigue, C. (2004). Learning from education to communicate science as a good story. Endeavour, 28(3), 120-124.

Nurani, E., \& Robiasih, H. (2017). Developing material for teaching grammar using macromedia flash software for junior high school.JELLT (Journal of English Language and Language Teaching), 1(1).

Pinter, A. (2017). Teaching young language learners. Oxford University Press.

Pratiwi, D. E. (2016). Pengembangan Media Flashcard Berbasis Macromedia Flash Pada Pembelajaranbahasa Indonesia Model Think Talk Write Untuk Meningkatkan Kemampuan Menulis Siswa Kelas IV Sekolah Dasar.Jurnal Review Pendidikan Dasar: Jurnal Kajian Pendidikan Dan Hasil Penelitian, 2(1), 105-111.

Ranchhod, A., \& Zhou, F. (2001). Comparing respondents of e-mail and mail surveys: understanding the implications of technology. Marketing Intelligence \& Planning.

Rapo, A., \& Michael, A. (2013). Understanding macromedia flash 8 actionscript 2: basic techniques for creatives. Routledge.

Saputra, H. J. A., \& Tiarina, Y. (2013). Using macromedia flash 8 to help English teacher to build media toward teaching reading. Journal of English Language Teaching, 1(2), 392-398.

Schultze, U., \& Boland Jr, R. J. (2000). Knowledge management technology and the reproduction of knowledge work practices. The Journal of Strategic Information Systems, 9(2-3), 193-212.

Selwyn, N. (2003). Apart from technology: understanding people's non-use of information and communication technologies in everyday life. Technology in society, 25(1), 99-116. 
Shagiyeva, N. (2020). The role of information technologies to teach Russian language. European Journal of Research and Reflection in Educational Sciences, 8(7).

Smith, L. E. (2015). English as an international language: No room for linguistic chauvinism. Journal of English as a Lingua Franca, 4(1), 165-171.

Simarmata, J., Chaerul, M., Mukti, R. C., Purba, D. W., Tamrin, A. F., Jamaludin, J., ... \& Meganingratna, A. (2020). Teknologi Informasi: Aplikasi dan Penerapannya. Yayasan Kita Menulis.

Simarmata, J., Sihotang, J. I., Karim, A., Purba, R. A., Hazriani, H., Koibur, M. E., ... \& Jamaludin, J. (2021). Literasi Digital. Yayasan Kita Menulis.

Sulistyawati, A., Wardono, W., \& Kartono, K. (2018). Pemanfaatan ICT Dalam Literasi Matematika. In PRISMA, Prosiding Seminar Nasional Matematika (Vol. 1, pp. 853859).

Trisna, A., \& Nasution, R. S. (2018). Developing Macromedia Flash for Teaching Speaking Materials for Students. In Proceeding of the 1st Annual International Conference on Language and Literature (Vol. 1, No. 1).

Waizenegger, L., McKenna, B., Cai, W., \& Bendz, T. (2020). An affordance perspective of team collaboration and enforced working from home during COVID-19. European Journal of Information Systems, 29(4), 429-442.

Wulanjani, A. N. (2016). The Use of Vocabulary-Games in Improving Children's Vocabulary in English Language Learning. Transformatika: Jurnal Bahasa, Sastra, dan Pengajarannya, 12(1), 76-83. 